Buana Sains Vol 20 No 1: 1 - 6, 2020

\title{
PENGARUH PENGGUNAAN LEMAK SAPI, MINYAK KELAPA DAN MINYAK KEDELAI DALAM PAKAN TERHADAP PERFORMA PRODUKSI AYAM PEDAGING
}

\author{
A.B.A. Mardhotillah ${ }^{1,2}$, , H. Darmawan ${ }^{4}$ I.H. Djunaidi ${ }^{2}$ L.C. Hsia ${ }^{3}$, Y.C. Chen ${ }^{1}$ \\ ${ }^{1}$ Department of Biological Science and Technology, National Pingtung University of Science and Technology, Taiwan \\ ${ }^{2}$ Fakultas Peternakan, Universitas Brawijaya, Malang, Indonesia \\ ${ }^{3}$ Department of Animal Science, National Pingtung University of Science and Technology, Taiwan \\ ${ }^{4}$ Program Studi Peternakan, Fakultas Pertanian, Universitas Tribhuwana Tunggadewi, Malang,Indonesia
}

\begin{abstract}
This experiment was conducted to evaluate the effect of various fat sources and their combination (coconut oil and soybean oil) on growth performance of broiler. A total of 80 one-day old female 1-d-old Arbor Acres were randomly assigned into four groups (4 treatment) with 10 replicates ( 6 birds per pen) within 42 days. The experimental groups consisted of four treatment of diets: 1) a basal-diet containing beef oil (BO), 2) a basal diet containing coconut oil (CO), 3) a basal diet containing soybean oil (SO), and 4) a basal diet containing coconut oil and soybean oil $(\mathrm{CO}+\mathrm{SO})$ as were used. Performance data were obtained during the feeding period. The result was shown that using combination of medium chain fatty acid and unsaturated fatty acid (CO+SO) were increased growth performance demonstrated by highest bodyweight (59.62 g) compared with other treatments $(\mathrm{P}<0.05)$ throughout the experimental period $(0-42$ days). The lower group for feed conversion ratio was obtained in the diet containing beef oil $(\mathrm{BO})$ compared with other groups $(1.32 ; \mathrm{P}<0.05)$. Feed consumption and bodyweight have significantly different $(\mathrm{P}<0.05)$ but not different for feed conversion ratio $(\mathrm{P}>0.05)$. It can be concluded that feeding combination $\mathrm{CO}+\mathrm{SO}$ in the diet may improve the performance of broiler.
\end{abstract}

Keywords: Beef oil; broiler; coconut oil; growth performance; soybean oil.

\section{Pendahuluan}

Periode dua dekade belakangan ini usaha industri peternakan terutama dunia perunggasan harus meningkatkan produksi jumlah karkas yang disebabkan telah terjadi peningkatan konsumsi daging ayam pedaging di masyarakat. Hal ini dikarenakan kesadaran masyarakat akan keseimbangan nutrisi dan kesehatan tubuh yang sangat penting. Peningkatan jumlah produksi karkas broiler yang optimal juga membutuhkan ransum pakan dengan kandungan nutrisi lainnya yang seimbang, selain itu kandungan energi metabolis yang tinggi sangat diperlukan agar pertumbuhan broiler optimal dan cepat, mengingat saat ini Antibiotic Growth Promotor (AGP) tidak lagi diperbolehkan penggunaannya dalam industri peternakan.

Perbaikan efisiensi penggunaan pakan dalam usaha peternakan broiler, menimbulkan perhatian pada produk karkas yang dihasilkan memiliki timbunan lemak pada abdomen (lemak abdominal) dan deposisi lemak dibawah kulit yang menyebabkan timbulnya resistensi pada manusia yang 
A.B.A Mardhotillah, H. Darmawan, I.H. Djunaidi, L.C. Hsia, Y.C. Chen/ Buana Sains Vol 20 No $1: 1-6$

mengkonsumsinya.

Perubahan komposisi lemak pada pakan dengan penambahan beberapa sumber lemak dari hewan dan tumbuhan tertentu diduga dapat meningkatkan waktu retensi pakan dalam usus atau memperpanjang laju alir, sehingga proses digesti dan absorpsi kontituens non lemak akan lebih sempurna (Sanz et al., 1999). Nitsan et al., 1997 mengungkapkan keuntungan kalori ekstra dari lemak umumnya diekspresikan dengan perbaikan pertumbuhan, efisiensi penggunaan pakan, dan tingginya kandungan energi metabolis pada pakan. Zollitsch et al., (1998) dan Sibbald et al., (1980) melaporkan bahwa performa produksi dan karakteristik lemak karkas broiler dipengaruhi oleh sumber lemak dalam pakan.

Penelitian ini bertujuan untuk membandingkan pengaruh penambahan lemak sapi, minyak kelapa dan kedelai serta kombinasi keduanya dalam pakan terhadap performa produksi yang dipelihara dalam temperatur yang berbeda.

\section{Metode Penelitian}

Penelitian ini menggunakan 80 ekor DOC (Day Old Chick) ayam pedaging ras pedaging Arbor Arcers dengan bobot awal rata-rata 45 gram yang dipelihara selama 42 hari. Selain itu, kandang individual yang dilengkapi dengan feeder dan drinker juga digunakan dalam penelitian ini.

Formulasi penambahan minyak dan lemak tersebut disusun sesuai dengan standar kebutuhan broiler yang telah disusun dengan jumlah seimbang dalam setiap pakan perlakuan yang ditunjukan pada tabel 1.

Metode penelitian ini menggunakan metode eksperimen dengan Rancangan Acak Lengkap (RAL) yang terdiri dari 5 perlakuan pakan. Pakan perlakuan terdiri dari:

BO: Pakan basal $+2.0 \%$ lemak sapi

CO: Pakan basal $+2.0 \%$ minyak kelapa

SO: Pakan basal $+20 \%$ minyak kedelai

$\mathrm{CO}+\mathrm{SO}:$ Pakan basal $+1,0 \%$ minyak kelapa $+1.0 \%$ minyak kedelai.

Setiap unit percobaan terdiri dari 10 ekor ayam pedaging. Pengukuran data performa ayam pedaging meliputi: konsumsi pakan yang diukur per hari, bobot badan dan rasio konversi pakan.

Data yang diperoleh dianalisis menggunakan General Linier Model (GLM), prosedur (SAS software institute, 1990). Jika terdapat perbedaan yang nyata diantara perlakuan dilanjutkan dengan uji Duncan.

\section{Hasil dan Pembahasan}

Hasil penelitian menunjukkan bahwa penambahan lemak sapi, minyak kelapa dan minyak kedelai serta kombinasinya dalam setiap perlakuan pakan menunjukkan perbedaan yang sangat nyata $(\mathrm{P}<0,01)$ ditunjukkan pada keluruhan, mulai dari minggu ke-1 hingga minggu ke-6 dalam eksperimen. Pengaruh pakan terhadap konsumsi pakan berbeda tidak nyata dihasilkan pada fase growing yaitu pada minggu ke-3 hingga fase finishing pada minggu ke6 antar perlakuan. Dibandingkan dengan pakan yang mengandung lemak sapi (BO) dan minyak kelapa (CO), pakan dengan kombinasi minyak kelapa dan kedelai $(\mathrm{CO}+\mathrm{SO})$ menunjukkan hasil konsumsi pakan tertinggi $(84.56 \mathrm{~g})$ pada minggu pertama sampai minggu terakhir penelitian yang diikuti dengan perlakuan SO (84.23 g). 
A.B.A Mardhotillah, H. Darmawan, I.H. Djunaidi, L.C. Hsia, Y.C. Chen/ Buana Sains Vol 20 No $1: 1-6$

Tabel 1. Komposisi Nutrisi Pakan Ayam Pedaging

\begin{tabular}{|c|c|c|c|c|}
\hline Komposisi (\%) & $\mathrm{BO}$ & $\mathrm{CO}$ & $\mathrm{SO}$ & $\mathrm{CO}+\mathrm{SO}$ \\
\hline Tepung Jagung & 60.93 & 60.93 & 60.93 & 60.93 \\
\hline Tepung Kedelai & 33.00 & 33.00 & 33.00 & 33.00 \\
\hline Lemak Sapi & 2.00 & - & - & - \\
\hline Minyak Kelapa & - & 2.00 & - & 1.00 \\
\hline Minyak Kedelai & - & - & 2.00 & 1.00 \\
\hline Premix* & 0.30 & 0.30 & 0.30 & 0.30 \\
\hline Garam & 0.30 & 0.30 & 0.30 & 0.30 \\
\hline Metionin & 0.23 & 0.23 & 0.23 & 0.23 \\
\hline Threonin & 0.02 & 0.02 & 0.02 & 0.02 \\
\hline Protein Kasar (\%) & 20.2 & 20.2 & 20.2 & 20.2 \\
\hline Kalsium & 1.05 & 1.05 & 1.05 & 1.05 \\
\hline Fosfor & 0.45 & 0.45 & 0.45 & 0.45 \\
\hline Lisin & 1.1 & 1.1 & 1.1 & 1.1 \\
\hline Metionin & 0.9 & 0.9 & 0.9 & 0.9 \\
\hline Threonin & 0.8 & 0.8 & 0.8 & 0.8 \\
\hline
\end{tabular}

Vitamin premix (per $\mathrm{Kg}$ of diet); vitamin A 10.000.000 UI; vitamin D3 1.000.000 UI; vitamin E 20 g; vitamin K3 1.5 g; vitamin B1 2 g; vitamin B2 4 g; vitamin B6 3 g;vitamin B12 15 g; D-calcium 60 g; D-pantotenic Acid 1 g; vinegaric Acid 35 g. Mineral premix (Per kg of diet); Titanium $100 \mathrm{mg}$; copper $5 \mathrm{~g}$; iodine $400 \mathrm{mg}$; iron $40 \mathrm{mg}$; zinc $44 \mathrm{~g}$.

Tabel 2. Hasil Penelitiaan Pengaruh Penambahan Sumber Lemak dalam Pakan Terhadap Performa Produksi Ayam Pedaging

\begin{tabular}{|c|c|c|c|c|c|c|c|}
\hline \multirow{2}{*}{\multicolumn{2}{|c|}{ Parameter }} & \multicolumn{4}{|c|}{ Perlakukan } & \multirow{2}{*}{ SEM } & \multirow{2}{*}{ Sign } \\
\hline & & $\mathrm{BO}$ & $\mathrm{CO}$ & $\mathrm{SO}$ & $\mathrm{CO}+\mathrm{SO}$ & & \\
\hline \multicolumn{8}{|c|}{ Konsumsi Pakan } \\
\hline \multirow[t]{3}{*}{ Minggu } & $1-2$ & $34.92^{c}$ & $38.07^{\mathrm{b}}$ & $40.25^{\mathrm{ab}}$ & $42.27^{\mathrm{a}}$ & 0.45 & $* * *$ \\
\hline & $3-4$ & $75.44^{\mathrm{b}}$ & $75.07^{\mathrm{b}}$ & $79.16^{\mathrm{a}}$ & $79.51^{\mathrm{a}}$ & 0.55 & $*$ \\
\hline & $5-6$ & $125.81^{b}$ & $126.10^{\mathrm{b}}$ & $133.29^{\mathrm{a}}$ & $131.90^{\mathrm{a}}$ & 0.62 & $*$ \\
\hline (Total) & $1-6$ & $78.73^{\mathrm{b}}$ & $79.75^{\mathrm{b}}$ & $84.23^{\mathrm{a}}$ & $84.56^{\mathrm{a}}$ & 0.48 & $* * *$ \\
\hline \multicolumn{8}{|c|}{ Bobot Badan } \\
\hline \multirow{3}{*}{ Minggu } & $1-2$ & 30.54 & 28.31 & 30.72 & 30.71 & 0.4 & NS \\
\hline & $3-4$ & $65.96^{\mathrm{a}}$ & $58.95^{\mathrm{b}}$ & $62.70^{\mathrm{ab}}$ & $63.84^{\mathrm{a}}$ & 0.6 & $*$ \\
\hline & $5-6$ & $77.25^{\mathrm{b}}$ & $74.74^{\mathrm{b}}$ & $74.03^{\mathrm{b}}$ & $83.32^{\mathrm{a}}$ & 0.7 & $* *$ \\
\hline (Total) & $1 \sim 6$ & $57.92^{\mathrm{ab}}$ & $54.00^{c}$ & $56.65^{\mathrm{bc}}$ & $59.62^{\mathrm{a}}$ & 0.5 & $* *$ \\
\hline \multicolumn{8}{|c|}{ Rasio konversi Pakan } \\
\hline \multirow[t]{3}{*}{ Minggu } & $1-2$ & $1.15^{\mathrm{b}}$ & $1.32^{\mathrm{a}}$ & $1.25^{\mathrm{a}}$ & $1.33^{\mathrm{a}}$ & 0.09 & $* *$ \\
\hline & $3-4$ & $1.15^{\mathrm{b}}$ & $1.34^{\mathrm{a}}$ & $1.29^{\mathrm{a}}$ & $1.25^{\mathrm{ab}}$ & 0.10 & $*$ \\
\hline & $5-6$ & $1.66^{\mathrm{b}}$ & $1.74^{\mathrm{b}}$ & $1.94^{\mathrm{a}}$ & $1.61^{\mathrm{b}}$ & 0.11 & $* * *$ \\
\hline (Total) & $1-6$ & $1.32^{\mathrm{c}}$ & $1.47^{\mathrm{a}}$ & $1.46^{\mathrm{a}}$ & $1.39^{\mathrm{b}}$ & 0.08 & $* * *$ \\
\hline
\end{tabular}

Keterangan: Notasi superskrip yang berbeda pada kolom yang sama menunjukkan perbedaan yang sangat nyata $(\mathrm{P}<0,01)$ dan perbedaan yang nyata $(\mathrm{P}<0,05)$ 
Hal ini disebabkan oleh kecilnya perbedaan kandungan energi ransum pakan dan perbedaan derajat kejenuhan dari asam lemak dalam ransum pakan memang tidak signifikan berpengaruh terhadap konsumsi pakan dan konversi pakan, seperti hasil penelitian Sanz et al. (2000). Konsumsi pakan lebih ditentukan oleh tingkat kandungan energi dalam pakan, broiler akan mengkonsumsi energi sedikit lebih banyak bila kandungan energi dalam ransum pakan meningkat. pengaruh palatabilitas pakan hanya punya peran yang relatif kecil. Pada fase growing, broiler umur 3-4 minggu ke atas akan berpengaruh terhadap tingkat konsumsi pakan dan pertumbuhan.

Konsumsi pakan pada perlakuan kombinasi $\mathrm{CO}+\mathrm{SO}$ cenderung lebih banyak dari pada perlakuan lainnya. Hal ini dikarenakan efek sinergisme antara minyak kelapa dan minyak kedelai, hal ini diduga karena perbedaan panjangnya rantai atom $C$ dari asam lemak jenuh dan asam lemak tidak jenuh yang terkandung dalam pakan.

Broiler yang mengandung pakan perlakuan BO memiliki tingkat konsumsi yang rendah, Bourdon et al.,1987 menyatakan lemak sapi dikenal lebih banyak mengandung asam lemak jenuh rantai panjang palmitat dan stearate dimana tingkat penyerapan nutrisi dalam pencernaan kurang optimal.

Pengaruh penggunaan lemak sapi, minyak kelapa dan kedelai serta kombinasinya dalam pakan tidak berpengaruh nyata $(\mathrm{P}>0,05)$ pada bobot badan di fase starter, namun setelah memasuki fase growing pada minggu ke-3 sampai ke-6 menghasilkan perbedaan yang nyata pada masing-masing perlakukan. Hasil lain diperoleh bahwa perlakuan $(\mathrm{CO}+\mathrm{SO})$ memperoleh bobot badan tertinggi $(59,62)$ dan sebaliknya bobot terendah $(54,00)$ terdapat pada perlakuan (CO). Penggunaan minyak dan lemak dalam ransum pakan akan meningkatkan pertumbuhan, karena: menurunnya laju alir (meningkatnya waktu retensi pakan dalam usus), sehingga proses digesti dan absorbsi nutrien lebih lengkap; rendahnya 'heat increment' dari ransum pakan yang menggunakan lemak menghasilkan peningkatan penggunaan energi metabolis (Sibbald and Kramer, 1980; Brue et al., 1985).

Perlakuan tidak berpengaruh nyata terhadap pertambahan bobot badan broiler pada fase starter, umur 1-14 hari, Pada broiler yang berumur lebih muda dan pertumbuhan sangat cepat, tetapi daya cerna masih rendah. Hal ini menunjukkan bahwa pengaruh penggunaan minyak dan lemak dalam pakan terhadap bobot badan dipengaruhi oleh umur broiler. Penambahan lemak dipengaruhi faktor umur unggas, pengaruh memperbaiki pertumbuhan dari lemak pakan ini akan nampak jelas pada ayam pedaging ketika kemampuannya mencerna lemak mendekati tingkat seperti ayam pedaging dewasa (Nitsan et al.1997).

Derajat kejenuhan lemak dari pakan berpengaruh terhadap penggunaan dan akumulasi lemak tubuh broiler, sehingga broiler yang mendapat pakan lemak hewan (lemak sapi dan lemak babi) menunjukkan penyimpanan lemak tubuh yang lebih tinggi dibanding dengan yang mendapatkan minyak yang bersumber dari tumbuhan. Hal ini dapat memperngaruhi bobot badan broiler. Deaton et al. (1981) yang menyatakan bahwa lemak tubuh meningkat dengan pemberian ransum pakan yang mengandung lemak sapi dibanding dengan yang mendapatkan ransum pakan minyak nabati, namun pernyataan ini tidak sejalan dengan Sanz et al. (2000) 
yang melaporkan bahwa sumber lemak tidak berpengaruh nyata terhadap pertambahan bobot badan, bobot badan, konsumsi pakan, dan konversi pakan broiler.

Hasil penelitian menunjukkan bahwa pakan yang mengandung perlakuan kombinasi $(\mathrm{CO}+\mathrm{SO})$ memiliki penampilan bobot badan yang tinggi dari pada perlakuan lainnya. Hal ini disebabkan karena penggunaan minyak nabati yang diekspresikan dengan meningkatnya pemanfaatan energi dalam pakan yang akan menyebabkan suatu penurunan konsumsi pakan, tetapi tidak mempunyai efek negatif terhadap pertambahan bobot badan harian (Laurin et al., 1985; Pinchasow and Nir, 1992; Nitsan et al., 1997).

Hasil analisis pada penggunaan lemak sapi, minyak kelapa dan kedelai serta kombinasinya dalam pakan dapat diperoleh perbedaan sangat nyata $(\mathrm{P}<0,01)$ dapat memperbaiki konversi pakan. Rata-rata pada perlakuan pakan $\mathrm{BO}$, hasil ratio koversi pakan menunjukkan paling rendah dibandingkan pakan perlakuan lain, terutama pada minggu pertama hingga fase growing, namun sebaliknya hasil berbeda sangat nyata $(\mathrm{P}<0,01)$ yaitu pada fase finishing yaitu minggu ke-5 dan 6 ratio konversi pakan yang efisien di peroleh pada pakan perlakuan kombinasi (CO+SO). Penelitian Zollitsch et al. (1997) menyimpulkan bahwa kelompok broiler yang mendapatkan sumber lemak ransum pakan minyak nabati (minyak kedelai dan minyak biji rami) mempunyai konversi pakan yang lebih baik dibandingkan dengan kelompok yang mendapatkan animal-vegetable fat blend (AVB) dan processed fat product (PFP). Hal ini disebabkan asam lemak dari PFP dan AVB dominan dengan asam lemak jenuh rantai panjang yang pada fase starter, metabolisme broiler lebih rendah dibandingkan dengan minyak nabati.

Penelitian ini menunjukkan pemberian pakan yang mengandung $\mathrm{BO}$ dapat memperbaiki ratio konversi pakan, hal ini disebabkan oleh penggunaan lemak sapi memberikan keuntungan efek kalori ekstra yang diekspresikan dengan adanya tingginya pemanfaatan energi dalam pakan, perbaikan pertumbuhan, efisiensi penggunaan pakan (Keren-Zvi et al., 1990: Nitzan et al., 1997). Brue et al. (1985) menyatakan bahwa bila broiler tidak menurunkan konsumsi pakannya sebagai respon lebih tingginya kandungan energi ransum pakan, berarti broiler mengkonsumsi lebih banyak ME per hari. Rosebrough et al. (1999) yang meneliti interaksi pengaruh level lemak dan protein dalam ransum pakan, mendapatkan bahwa penggantian kalori karbohidrat ransum pakan dengan kalori dari lemak tidak mempengaruhi bobot tubuh, konsumsi pakan, dan efisiensi penggunaan pakan.

\section{Kesimpulan}

Penggunaan kombinasi minyak kelapa dan minyak kedelai pada pakan meningkatkan konsumsi pakan broiler pada fase finishing, sedangkan pada broiler yang diberi pakan yang mengandung lemak sapi dapat memperbaiki nilai ratio konversi pakan pada fase starter hingga finishing.

Pertambahan bobot badan broiler fase growing tidak dipengaruhi oleh jenis minyak, namun pada fase finishing penggunaan pakan yang mengandung kombinasi minyak kelapa dan minyak kedalai dapat meningkatkan pertambahan bobot badan broiler. 
A.B.A Mardhotillah, H. Darmawan, I.H. Djunaidi, L.C. Hsia, Y.C. Chen/ Buana Sains Vol 20 No $1: 1-6$

\section{Daftar Pustaka}

Bourdon, D., C. Fevrier, B. Leclercq, M. Lessire, and J.M. Perez. 1987. Comments on raw materials. In : Feeding of Non-Ruminant Livestock. (J. Wiseman, Ed.). Butterworth \& Co. Ltd., London. pp 123-129.

Deaton, J.W., J.C. McNaughton, F. Reecho, and B.D. Lott. 1981. Abdominal fat of broilers as influenced by dietary level of animal fat. J. Poultry Sci. 60 : 1250-1253Wahyu. 2004. Ilmu Nutrisi Unggas. Edisi ke 5. Gajah Mada University Press. Yogyakarta.

Keren-Zvi, S., Nir, I., Nitsan. Z., and A. Cahaner. 1990. Effect of dietary concentration of fat and energy on fat deposition in broilers divergently selected for high or low abdominal adipose tissue. Br. Poultry Sci. 31: 507-516.

Nitsan, Z., A. Dvorin, Z. Zoref, and S. Mokady .1997. Effect of added soyabean oil and dietary energy on metabolizable and net energy of broiler diets. Br. Poultry Sci. 38 : 101-106.

Rosebrough, R.W., J.P. McMurtry, and R. Vasilatos- Younken. 1999. Dietary fat and protein interaction in the broiler. J. Poultry Sci. 78:992- 996.

Sanz, M., A. Flores, and C.J Lopez-Bote. 2000. The Metabolic use of energy from dietary fat in broiler is affected by fatty acid saturation. Br. Poultry Sci. 41 (1):61-68.

Sanz, M., A.Flores, P.P. De Ayala, and C.J Lopez- Bote. 1999. Hihger lipid accumulation in broilers fed on saturated fats than in those fed on unsaturated fats. Br. Poultry Sci. 40 (1):95-101.

Sibbald, I.R and J.K. Kramer. 1980. The effect of the basal diet on the utilization of fat as a source of true metabolizable energy, lipid, and fatty acids. J. Poultry Sci. 59(2):316-24.

Zollitsch, W., W. Knaus, F. Aichinger, and F. Lettner. 1998. Effects of different dietary fat sources on performance and carcass characteristics of broilers. Anim. Feed Sci. Technol. 66 (1- 4):6373. 